\title{
Gastrointestinal parasites in goats from Monte Castelo, Santa Catarina, Brazil
}

\author{
Parasitas gastrintestinais em caprinos de Monte Castelo, Santa Catarina, Brasil \\ Cristina Perito Cardoso ${ }^{1 *}$; Leonardo Leite Cardozo²; Bruna Fernanda da Silva ${ }^{3}$; \\ Alessandro Francisco Talamini do Amarante
}

\begin{abstract}
${ }^{1}$ Laboratório de Sanidade Animal, Estação Experimental de Lages, Empresa de Pesquisa Agropecuária e Extensão Rural de Santa Catarina - EPAGRI, Lages, SC, Brasil

${ }^{2}$ Mestrado em Ciência Animal, Centro de Ciências Agroveterinárias - CAV, Universidade do Estado de Santa Catarina - UDESC, Lages, SC, Brasil

${ }^{3}$ Instituto de Biociências, Departamento de Parasitologia, Universidade Estadual Paulista - UNESP, Botucatu, SP, Brasil
\end{abstract}

Received April 28, 2011

Accepted June 28, 2011

\begin{abstract}
This study was carried out with the aim of estimating the degree of gastrointestinal helminth infection in goats on the Northern Plateau of Santa Catarina. Twelve young females and 11 adult females were used. Every 28 days, feces samples were taken to quantify the nematode eggs per gram of feces (EPG). Larval culturing was performed on a pool of positive samples from the same group. The fecal egg counts (FECs) ranged from zero to 10,400 EPG in the young group and zero to 7,600 EPG in the adult group. The mean FECs were between 583.3 and 4441.7 in the young group and between 418.2 and 2181.8 in the adult group. Eggs of the order Strongylida and genera Moniezia and Toxocara, and oocysts of Coccidia, were observed. The young animals were more affected and Haemonchus was the most prevalent genus in the samples.
\end{abstract}

Keywords: Goats, parasitosis, Haemonchus.

\section{Resumo}

Este trabalho foi realizado com o objetivo de estimar o grau de infecção dos helmintos gastrintestinais em um rebanho caprino criado no Planalto Norte Catarinense. Foram utilizadas 12 fêmeas jovens e 11 adultas, das quais, a cada 28 dias, foram coletadas amostras de fezes diretamente do reto, totalizando 12 coletas, para quantificação de ovos por grama de fezes (OPG) e cultivo de larvas através de "pool" das amostras positivas do mesmo grupo. A contagem de OPG variou de zero a 10.400 nos animais jovens e de zero a 7.600 nos adultos. As médias do OPG entre as coletas foram de 583,3 a 4.441,7 no grupo jovem e de 418,2 a 2.181,8 nos adultos, sendo observados ovos da ordem Strongylida, dos gêneros Moniezia e Toxocara, bem como oocistos de coccídeos. Os animais mais jovens foram os mais acometidos, sendo o gênero Haemonchus o mais prevalente.

Palavras-chaves: Caprinos, verminose, Haemonchus.

The small ruminant industry is an expanding activity that is widely practiced in Brazil, especially in the Northeast region. However, goat farming has also been gradually implemented in other states, including Santa Catarina, which today has a population of about 40,000 goats (IBGE, 2006). Goats are widely exploited in tropical countries for meat, milk and skin production.

\footnotetext{
*Corresponding author: Cristina Perito Cardoso

Laboratório de Sanidade Animal, Estaçáo Experimental de Lages, Empresa de

Pesquisa Agropecuária e Extensão Rural de Santa Catarina - EPAGRI,

Rua José Joāo Godinho, s/n, Morro do Posto, CP 181,

CEP 88502-970, Lages, SC, Brasil

e-mail: cristinaperito@yahoo.com.br
}

Gastrointestinal parasitism is an important factor in economic production losses among small ruminants and is considered to be their most serious health problem. This parasitism occasionally makes goat-rearing impracticable (BUZZULINI et al., 2007).

The success of any worm control program among goats and sheep is directly related to knowledge of the population dynamics of the free-living stage in the environment and the parasitic phase in animals (MACIEL et al., 2006).

The present study aimed to estimate the degree of infection and some epidemiological data on gastrointestinal helminths in a goat herd on the Northern Plateau of Santa Catarina.

The study was carried out from January to December 2009 on a farm property in Monte Castelo, state of Santa Catarina, 
which during the experimental period had a total of 138 goats without defined breed. The experimental animals were grouped randomly; for this, 12 young females (6-8 months of age) and 11 adult goats without defined breed (over 12 months of age) were used. The animals were individually identified with numbered ear tags and kept together with the general flock. The goat were kept in an exclusive area composed of 2 hectares (ha) of winter pasture (Avena sp. and Lolium sp.) and 5 ha of summer pasture (Axonopus catarinensis and Brachiaria sp.), as well as native field and meadow plants, thus totaling 24 ha with a stock density of 0.5 animal unit/ha.

Every 28 days, feces samples were collected directly from the rectum to determine the number of nematode eggs per gram of feces (EPG) (GORDON; WHITLOCK, 1939). Fecal culturing was performed to identify the genera of infective larvae (L3), on a pool of positive samples from the same group (UENO; GONÇALVES, 1998).

In order to avoid cases of mortality, in situations when symptoms of helminthosis such as pale mucous membranes, bristling and opaque hair, weight loss and submandibular edema and/or fecal egg counts (FECs) of greater than 4000 EPG (AMARANTE et al., 1999) were observed, all the experimental individuals were treated with the objective of maintaining similar sanitary conditions. For this, $5 \%$ levamisole hydrochloride was used orally, subsequently replaced by $10 \%$ albendazole $+1.35 \%$ cobalt sulfate.

The average monthly rainfall, temperature and humidity records were obtained from the specialized Epagri meteorological station, located in Major Vieira, Santa Catarina. The data were subjected to one-way analysis of variance and the means were compared using the Tukey test with a 5\% significance level (Minitab, version 11). The data were analyzed after $\log (\mathrm{x}+1)$ transformation.

Among the 276 samples analyzed during the experiment, $94.57 \%$ were positive for gastrointestinal parasites. Of these, $47.46 \%$ were parasitized exclusively by nematodes of the order Strongylida; $27.90 \%$ by Strongylida and Coccidia; $10.14 \%$ by Strongylida, Coccidia and Moniezia; $3.99 \%$ by Strongylida and the genus Moniezia; $3.62 \%$ only by Coccidia; $0.72 \%$ by Coccidea and Moniezia; $0.36 \%$ by Strongylida, Coccidia and Toxocara; and $0.36 \%$ only by Toxocara.

In the state of Paraíba, Martins Filho and Menezes (2001) found that $80.72 \%$ of the goat feces samples analyzed were positive for parasites, but in addition to what was seen in the present study, they also found Trichuris and Strongyloides. With regard to parasitism by Strongylida in the present study, $89.86 \%$ of the samples were positive. In the young and adult groups, 95.83 and $83.33 \%$, respectively, eliminated eggs of these parasites in their feces. The FEC ranged from zero to 10,400 in the young animals and from zero to 7,600 in the adults. The mean FECs for all the collection times were between 583.3 and 4441.7 in the young animals and between 418.2 and 2181.8 in the adult animals. Eggs of Moniezia spp. and Toxocara spp. and coccidian oocysts were also observed. In the adult group, fecal egg elimination was found in 73 to $91 \%$ of the animals, varying according to the collection month. In the young animals, this ranged from 83 to $100 \%$. In March and September, all of the young animals shed Strongylida eggs in their feces.

Larvae of Haemonchus spp., Cooperia spp., Trichostrongylus spp., Ostertagia spp. and Oesophagostomum spp. were identified in fecal cultures. Haemonchus was present in over $50 \%$ of the samples at most of the collection times, except in September and November, when Ostertagia was also abundant. Similar results were observed by Mattos et al. (2003) in Porto Alegre, Rio Grande do Sul, where they also found high prevalence of Haemonchus. Contrasting results were found in goats from the region of Porto Alegre, where Cardoso and Oliveira (1993) observed the presence of Nematodirus, Bunostomum, Strongyloides and Trichuris. However, this was due to the variation of parasites between different herds and regions. One important difference found in the present study was the occurrence of the genus Ostertagia, which has only been observed in this study and in those conducted in the Porto Alegre region.

This was the first study on goat parasitism in the state of Santa Catarina, where previously only studies on sheep were published, by Ramos et al. (2004). As such, further investigations involving a larger animal group and necropsy are needed in order to provide identification and epidemiological data for parasite species present in goat herds in Santa Catarina.

Correlation coefficients between climatic data (temperature, humidity and rainfall) and FEC were low $(-0.3 \leq r \geq 0.28)$ in both groups of the present study. Brito et al. (2009) demonstrated that parasitism was more prevalent in the rainy season, particularly in males, both in goats and in sheep, which was not observed in this study. This was possibly because the humidity was above $72 \%$ and the mean temperature was higher than $12.8{ }^{\circ} \mathrm{C}$, at all experimental times, and these climatic factors favored development of parasites in the flock evaluated. As such, infection remained high throughout the months of the year, even in the coldest months, especially in the young animals.

The group of young animals was more affected by parasites $(p<0.05)$, thus corroborating other reports in the literature showing that the age of these animals is inversely correlated with parasitism. After previous infection with gastrointestinal nematodes, young animals acquire some resistance to the pathogenic effects of these parasites (MARTINS FILHO; MENEZES, 2001).

Concluding, $94.57 \%$ of the samples were positive for gastrointestinal parasites, and the genera Haemonchus, Cooperia, Trichostrongylus, Ostertagia, Oesophagostomum, Moniezia and Toxocara were identified. The young animals were more affected and Haemonchus was the most prevalent genus.

\section{References}

Amarante AFT, Craig TM, Ramsey WS, Davis SK, Bazer FW. Nematode burdens and cellular responses in the abomasal mucosa and blood of Florida Native, Rambouillet and crossbreed lambs. Vet Parasitol 1999; 80(4): 311-324. http://dx.doi.org/10.1016/ S0304-4017(98)00229-5

Brito DRB, Santos ACG, Teixeira WC, Guerra RMSNC. Parasitos gastrintestinais em caprinos e ovinos da microrregião do Alto Mearim e Grajaú, no Estado do Maranhão, Brasil. Cienc Anim Bras 2009; 10(3): 967-974.

Buzzulini C, Silva Sobrinho AG, Costa AJ, Santos TR, Borges FA, Soares VE. Eficácia anti-helmíntica comparativa da associação albendazole, levamisole e ivermectina à moxidectina em ovinos. Pesq Agropec Bras 2007; 42(6): 891-895. http://dx.doi.org/10.1590/ S0100-204X2007000600017 
Cardoso JLS, Oliveira CMB. Fauna parasitária de caprinos na grande Porto Alegre. Rev Bras Parasitol Vet 1993; 2(1): 57-60.

Gordon HM, Whitlock AV. A new technique for counting nematode eggs in sheep feces. J Counc Sci Ind Res 1939; 12: 50-52.

Instituto Brasileiro de Geografia e Estatística - IBGE. Censo Agropecuário [online]. 2006. Available from: www.ibge.gov.br.

Maciel FC, Ahid SMM, Moreira FRC. Manejo sanitário de caprinos e ovinos. In: Lima GFC, Holanda Júnior EV, Maciel FC, Barros NN, Amorim MV, Confessor Júnior AA, organizadores. Criação familiar de caprinos e ovinos no Rio Grande do Norte: orientaçôes para viabilização do negócio rural. Natal: SINTEC; 2006. p. 391-426.
Martins Filho E, Menezes RCAA. Parasitos Gastrintestinais em Caprinos (Capra Hircus) de uma criação extensiva na Microrregião de Curimataú, estado da Paraíba, Brasil. Rev Bras Parasitol Vet 2001; 10(1): 41-44.

Mattos MJT, Oliveira CMB, Gouvea AS, Andrade CB. Sensibilidade dos nematódeos gastrintestinais de caprinos ao ivermectin na regiáo da Grande Porto Alegre, RS. Acta Sci Vet 2003; 31(3): 155-160.

Ramos CI, Bellato V, Souza AP, Avila VS, Coutinho GC, Dalagnol CA. Epidemiologia das helmintoses gastrintestinais de ovinos no Planalto Catarinense. Cienc Rural 2004; 34(6): 1889-1895. http://dx.doi. org/10.1590/S0103-84782004000600034

Ueno H, Gonçalves PC. Manual para diagnóstico das helmintoses de ruminantes. 4th ed. Tokyo: Japan International Cooperation Agency; 1998. 143 p. 